\title{
The Development of the Deprived Urban and Rural Areas, Ingrained with the Tourist Attractions (with an Emphasis on the Silk Road)
}

\author{
Nasrollah Fallah Tabar \\ Department of Human Ggeography, Rural Planning, Yadegar-e-Imam Khomeini (RAH), Shahr-e-Rey Branch, Islamic Azad \\ University, Tehran, Iran \\ Email: fallahtabarnasrollah@gmail.com
}

How to cite this paper: Tabar, N.F. (2017) The Development of the Deprived Urban and Rural Areas, Ingrained with the Tourist Attractions (with an Emphasis on the Silk Road). Open Journal of Geology, 7, 1569-1577. https://doi.org/10.4236/ojg.2017.710105

Received: January 18, 2017

Accepted: October 28, 2017

Published: October 31, 2017

Copyright (c) 2017 by author and Scientific Research Publishing Inc. This work is licensed under the Creative Commons Attribution International License (CC BY 4.0).

http://creativecommons.org/licenses/by/4.0/

\begin{abstract}
Around the year $140 \mathrm{BC}$ the Evo, the famous imperial Han Dynasty took power in China and then sent some representatives to the western land in order to communicate with the West in addition to know the political, military, geographical, economic and cultural situations of that region, it provides the basis for opening the way to the West. In this regard, they traveled to Iran and accordingly the formal relations were established between the Iranian and the Western governments and finally the Silk Road with a distance of about 8000 $\mathrm{km}$ has been emerged and started from the East and ended to Mediterranean Sea in the West. The aim of this study is to show that the Silk Road links throughout the world and its people together in thousands of years and the countries, cities and villages located in this road have been affected by developments or had affected and vivifying of it will lead to develop of the deprived urban and rural areas according to the abundant tourist attractions. This study which has used the historical and analytical method with practical purpose shows that cultural, scientific, religious and commercial exchanges between East and West were wide and many cities and villages were profiting of this gift. In this regard, vivifying of this road will lead to grow the underserved urban and rural areas according to many tourist attractions of the cities and villages.
\end{abstract}

\section{Keywords}

Development, Deprived Areas, The Cities And Villages, Tourist Attractions, The Silk Road 


\section{Introduction}

As yet many cities and villages of our country have distance with the development and so many resuscitative plans should be done in this regard. On the other hand, while all the towns and villages of our country are living in privation, but they have many tourist attractions. So if this road reestablishes again and necessary interactions and principles such as taking advantage of the urban and rural tourist attractions and geographical, historical, religious, scientific, cultural and archeological capabilities appear around the countries of this area, in this case the cities and villages located along the road will grow.

Researches show that the communication is the foundation of every society and brings it the growth and development. The Silk Road was the most important linked bridge between peoples and nations of that time and has had this heavy historical and unforgettable burden on its shoulders for hundreds years.

Also the most commercial products have been shipped between China and Europe, which the largest and most famous of these products was the Silk that the Silk Road takes its name from that and (Baron Ferdinand von Richthofen) was called it the Silk Road in the 19th century [1].

However, revival of the Silk Road more than 8000 kilometers with the assistance and cooperation of all nations in its path can result in area attractions that can cause the development of deprived towns and villages.

\section{The Issue of Research}

As Iran has been in place that is excelled compared to many other countries in many ways, the cities and villages should be deprived of their development path in order to do not drop behind of the other developed places and in this regard, using of the tourism industry which is called the world's third largest industry, is very fruitful and we can push the cities and villages placed along this road to flourish and develop by vivifying it.

So this question arises whether taking full advantage of the tourist attractions of the cities and villages they will be in the arena of development or not? And whether this will be achieved with the revival of the Silk Road?

\subsection{Research Hypothesis}

It seems that using planning and comprehensive development of the tourist attractions can lead to deprive of towns and villages smoothly, so the revival of the Silk Road in this area is effective.

\subsection{Research Methodology}

It is clear that complete investigation of deprived cities and villages and also past situation of the Silk Road which is rooted in a different eras requires to return to the pass in order to achieve to the actual result. Therefore in this research we use the descriptive-analytical technique in addition to the historical method by considering the prosperity and decline of the Silk Road in various ages and also ex- 
isting of urban and rural tourist attractions along this ancient road.

\subsection{Foundations, History and Theoretical Framework of Issue}

It is obvious that the tourist attractions and natural landscapes depend on features that the human eye can see and the other senses are able to be perceived [2].

In general, the development of tourism is the result of factors such as income levels, increased leisure time work, the development of transport, valuable exploration of geographic and length of stay in the country or region.

Also, the two core objectives of rural development planning are the welfare of rural residents and protecting the natural environment of the biological system of interest [3]. Urban planning framework is based on development plans and programs to meet the social and economic expectations and it creates the right physical structure to provide a decent life and acceptable residents [4]. On the other hand, long-term planning in tourism, paying particular attention to setting goals, tourist destinations, and long-term development patterns focus on sustainable development [5].

Research shows that the development of cities and villages must be made in comprehensive way to ensure the ultimate purpose and one of the important aspects of it is existence of the tourist attractions in these places. In this regard, the Silk Toad is the real witness from the past until its wane which has linked the all around the world and its people in thousand years and the countries, cities and villages placed along this road have taken advantages of it. However, today the connection between nations has been weakened and vivifying of the Silk Road can establish this connection again and they may take advantage of this road more than ever.

It is clear that this road has an especial important from the beginning to the end of the era of greatness. So it is worth that the countries, underline their determination and try to vivify this famous road with empathy and attunement and by using of the tourist attractions of the deprived cities and villages save them from the retardation and pave the path of development.

\subsection{The Position of the Studied Range}

The studied range of this research is very broad. It includes all of the developed and undeveloped cities and villages and knowing them from the development viewpoint and also includes from the east to the west and from the china to the Mediterranean Sea and all countries between these two places which extended along the $8000 \mathrm{~km}$ from the how to emerge viewpoint. Iran has played the role of a strong and valuable linking bridge and still can play this important role. Figure 1 and Figure 2 shows the Map of Silk Road.

Wen Shyayvshen, China has sent, said: Building Strategic Economic bar in the 21century, Silk Road and Maritime Silk Road between Middle-eastern countries is Inclination and basic international common interest expanded [6]. 


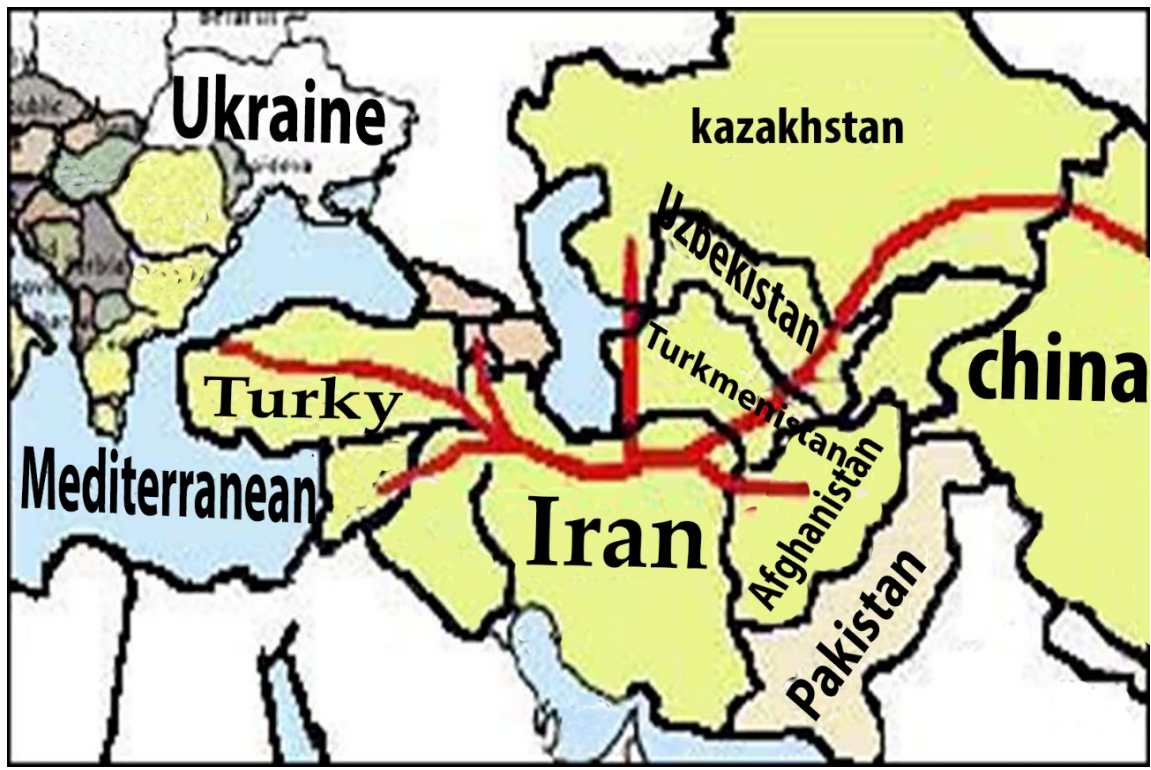

Figure 1. Map of Silk Road from China to the Mediterranean.

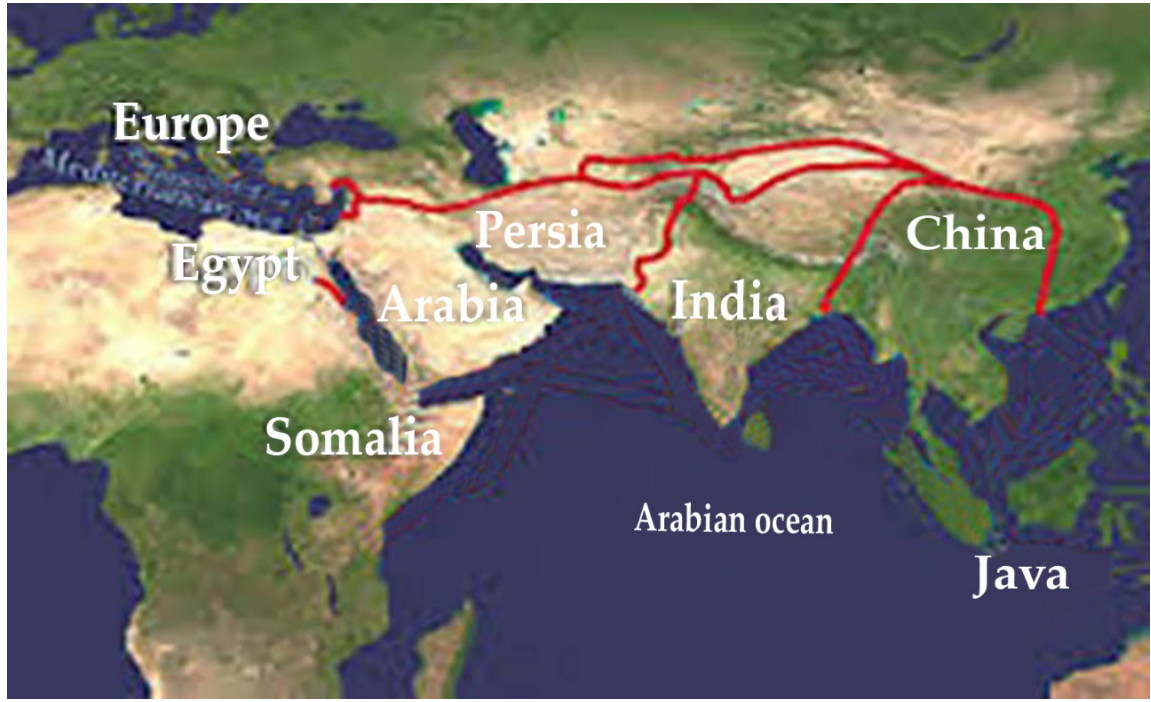

Figure 2. Map of Silk Road from China to the Mediterranean.

\section{Analyzing the Results of Research and Evaluation of Hypotheses}

Researches show that the Emperor of China tried to export Chinese silk to the West. To this end, it appointed a lot of manpower and huge capitals in order to make the most benefit from the Silk Road. He was successful to create a great way and full of caravansary in the northern and southern shores of the Desert (Taklamakan) that has extended beyond the Pamirs and joint to the center, West and South of Asia from there and sold his Silk in there.

The old way it is called that name because the Chinese silk, the most important property that was shipped in this way, is reached from this way to the West. The Silk that exchanged in this way, contrary to the opinion of some researchers, 
not only the demand of China but also it was produced the abundant Silks in the territories of China and even Iran and brought to the Western lands from this way.

However, the Silk Road was started from the Xi'an or Chang'an and ended to the Kashgar after passing from the Gansu Wall which has a special beauty and landscape. The Tarim plateau has the length of $1500 \mathrm{~km}$ and the width of 750 $\mathrm{km}$ and the mountains with height of 6000 meters are placed in the north, south and the west and it is ended to the Gobi Desert from the east and the famous Taklamakan Desert is around it.

Among the sub-ways of the Silk Road, there was one road that went to the south and ended to Mobility and transportation of goods and increase the wealth and prosperity were only in the shadow of the development and construction of the road network and the road safety which at the time of Great Darius and his initiative reached to its highest level. Building, maintaining and operating of more than $20000 \mathrm{~km}$ that about $2650 \mathrm{~km}$ of it was the King's Road (Military road) and also more than $1500 \mathrm{~km}$ of it was the commercial roads network. So, it seems that the Sub-ways and old ways have joined to the Great Silk Road [7].

These policies led to Iran seem as an impenetrable and intrusion prevention Silk Road to protect more enemies, foreigners, especially Turks, Iran impermeable [8].

It is noteworthy that the geographical context of the Silk Road has contained the most beautiful geographical landscapes and the most dangerous climatic conditions and the most fearsome ridges and thalwegs. Beautiful environments and the violence of its long path and also encounters that has occurred along the way by the enemies, pirates and ransom earners are always remembered in mined and has been quoted chest by chest. This matter is the reason of grandeur of the Silk Road. Although the history of life in mentioned plates have many hundred years old, but clearly it is related to the age of constituting of the Medes and Achaemenid Empire [9].

It is important that in every era of prosperity or demise of the Silk Road, the rulers of Iran had established the necessary security on this road, so every efforts of the West to bypass the Iran and to remove the Silk Road from it were inconclusive. Therefore, Iran can still take the advantages of the Silk Road by developing the deprived cities and villages and also by exchanging the ideas with the countries placed along the Silk Road. Figure 3 and Figure 4 shows the map of Silk Road from East to West.

\section{An Overview of the Tourism Attractions of Cities and Villages in the Silk Road Field}

The tourism attractions of Iranian cities and villages particularly deprived cities and villages are too much. So it will be mentioned some of the tourism attractions of the eastern and western provinces of Iran which placed in the basic path of the Silk Road and the most of the Silk caravans passed from them. 


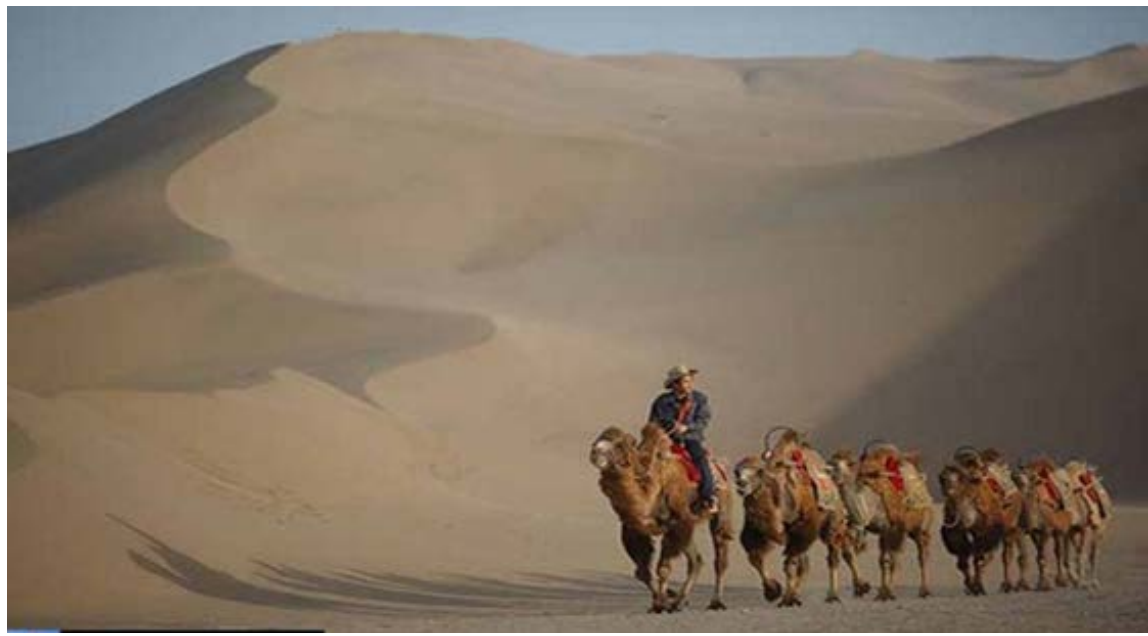

Figure 3. Part of the Silk Road in the sands.

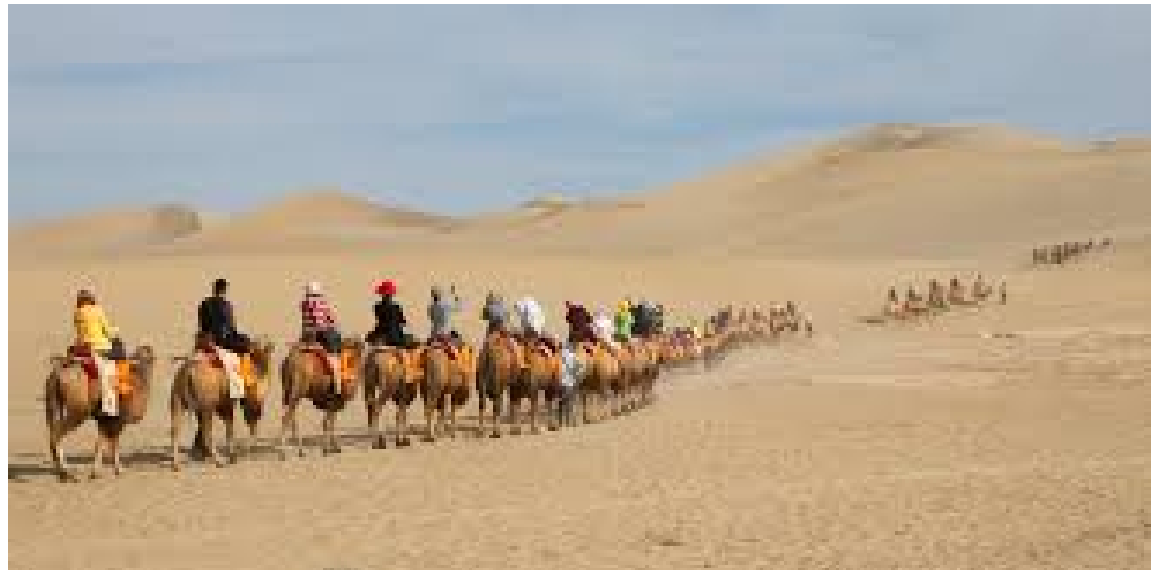

Figure 4. Part of the Silk Road in the sands.

1) Sistan and Baluchestan Province: Hamoun lake and its Toutans (traditional boats) in Zabul and recreational area Chahnimeh in Zabul, Mkrzn tree (Ficusreligiosa) in the Nickshahr and Miss caves, Birk, Kzvr, Multan mountains and Pouzebagh Hot spring, Bozman.

2) Khorasan Razavi, North Khorasan and South Khorasan Provinces: Akhmlh waterfall located in Chenaran, tourism areas like Monjaq Tappeh and Yusuf Khan in Quchan, Ferar garden in Kashmar, tourist areas in outskirt of Mashhad and Nation garden and Neshat garden in Mashhad and the tourism village Khan Mohammad located in Neyshabur. Baba Amanpark located in Bojnord. Rahim Abad Garden and Mansion, Shaukat Abad Gardens and Mansion in Birjand. Caves: Faghan Cave, Atashgah, Bidak, Akhlmr, Bidokht, Bazangan, Putin Doze, Baghcheh, Bymarab, PardeRustam, Khesht, Rosy, Dozdak, Kardeh, Konajke, Mzngan, Handel Abad, Mozduran, Khonik Pars, Behesht, Chenesht. The hot springs: Shahan Garmab, Garmab, Besh Ghardash.

3) Golestan Province: Lowe waterfall Maran castle in Minoo Dasht, rodeo horses racing event in Gonbad-e Qabus, Baran Kuh waterfall, Ziarat waterfall, 
Rango waterfall and fountain, Golestan National Park, Alang Valley (Tourism area), The Tourism area of Nahar Khoran Gorgan, Forest Park Imam Reza (aS) in Kordkoy, Kaboodval waterfall, Zarin Goli forest Park in Ali Abad, flower garden hall in Ramian, Ramian waterfall, nature and landscape of Mian Kaleh in the Turkmenbashi port [10].

4) Mazendaran Province: Dasht-e Naz National Park in Sari, Forest Park of Sisangan, the Botanical Garden of Noshahr, Mirza Koochak Khan forest park in Amol, Chaldare forest park in Tonekabon, Namakabroud Gondola lift in Chaloos and Espahbod Caves, Khorshid, PirzanKhani, Dyvsfyd Kyja Kachal, GoleZard, Hutu, Shirabad, Siahpoor, Hyldv, Khorramabad, Eshkevarat and Ab Ask hot springs, Sadat Mahaleh, Sakhtsar, Larijan, Katalem.

5) Gilan Province: Beautiful landscape of Masooleh in Fooman, Lonak waterfall, landscape and natural areas of Deilaman located in Siahkal, landscape of Manjil and Sefid Rood in Roodbar, Sjyrann waterfall in the Roodsar, old garden Mohtasham (Quds Park) located in Rasht, 90-year-old coastal park in Anzali port, Lavandevil waterfall, natural landscape of Heyran and Abbas Abad garden in Astara.

6) Tehran Province: Tong Vashti and its natural landscape in Firuzkuh, Do Qole waterfall in and Afghan caves in Shemiranat, Anbahun, Palang, Shel Ganj, Afshan river, Yakh Kand, Yakh Morad and hot springs of fountain of Ala, Dokhtar castle, Abali.

7) Qom province: GonbadeSabz garden in Qom and Kohak cave.

8) Isfahan Province: Fin Garden and Niasar waterfall in Kashan, Rosewater sampling in Ghamsar, Moorchekhort plain in ShahinShahr, birds garden and ChahArazeh caves in Isfahan, Palang, Ghahreman, Kalahrod, Helabad, Niasar and Dartun hot spring, Mahalat.

9) Semnan Province: Shahmirzad tourism area and Darband caves, Noravan, Shirband, Daghe Kashkouli (Afghans prison) and Semnan hot spring.

10) Qazvin province: KholehKooh hill and Avan Lake and Angool caves in Takestan, JajetKhane, Shams Kalayeh, Vali and Buin Zahra hot spring.

11) Zanjan province: Sharshar waterfall in Zanjan, Ghaterchi Darband (one of the early human settlement centers) in Mahneshan and Palangan caves, Tavdan, Chelleh Khane, Chehar Ashgoft, Shapur, Ghand Ab king, Zahhak, Band castle, Pirzan, SiyahChal, dungeons, Kan Gohar, Gorkan, Kalatak, Zacharia, Geber, Pelleh, Safaq, Khojast, Allama Jalaluddin Davani, Katalekhor, Kharmanesar, Bezj, JarehQāyeh Si, Jake Gol, AlamKandi, Qurrlu and Qushkar \& Vatnaq hot spring.

12) Hamedan province: Sarkan seven old girded Plane tree in Tuysarkan, Goorab located hill in Malayer, Tuliplands of Ghaleabad village in Nahavand, Ganjnameh waterfall, tourism and recreational building of Abbasabad and Mosali hill and Hegmataneh hill and also Agh Ghaya caves in Hamedan, Barge Lije, Baglyjeh, Shahir, Azad, Takht, Faraj valley, Sardkuh, Ali Sard, Juq castle, Gamasiab, Hiraj, Khurzaneh, Avarzaman, Gorz, Shahrestaneh, Ghahreman, Buzineh, 
Jard, Giyan, Farsian, Malusan, Banafsheh, Pyrsalman, Sarab, Sue Shi, HamehKasi [11].

13) East Azerbaijan Province: AsiabeKharabe waterfall and Kabootar caves in Jolfa, AqBulaq, Dvglyjan, Eskandar, Besley and Hampvyl and Khalkhal hot spring, Sareyn, Pooshaki, Qnyrjh, Ilando, Moobel, Bostanabad, Sarab, Alahaq.

14) West Azerbaijan Province: Urmia vineyards, Band and Nazloo park and walkway in Urmia, ancient hills in the center of Bukan, landscapes and mountains in Piranshar, Shalmash waterfalls and big Boring caves located in Sardasht, small Boring, Takht-e Soleiman, Sohoolan and Bash Kandi hot spring, Shah Abad, Haftabeh, prison of Solomon, Qaranjeh, Khan, Isi Su.

By considering the mentioned items, the Research hypothesis will be proved because it is clear that all of the villages and cities placed in the eastern and western provinces of Iran and have many tourist attractions will develop by developing of the Silk Road.

\section{Effective Results of the Tourism Development by Vivifying the Silk Road}

It will be emerged many results in developing and expanding the tourism Industry that in addition to the development of deprived cities and villages located on the Silk Road they are important from the national view:

1) Tourists entering to the country will increase the exports.

2) If people spend their vacations in the host country it will be as a substitution for imports. So receiving the tourists is effective to increase exports.

3) Tourists entering to the country will lead to more knowledge and a better understanding of the country's facilities for foreigners and provides the requirements for foreign investment.

4) The investment to provide the facilities will lead to attract revenues from the area of savings and fall them to the economic system of country and the transportation system of air, land and naval will be developed.

5) International exchanges and cooperation will be increased and expanded.

6) The utilizing of the constructed facilities and also the other investments will be optimal [12].

\section{Conclusions and Suggestions}

By considering the capabilities of the Islamic homeland and by using of the suitable planning we can improve the tourism industry in the country along with the developing of the tourist areas and deprived towns and villages and certainly the reappearing of the Silk Road will help this valuable movement.

Thus it is worthy to identify all of the deprived cities and villages especially villages that placed in the path of the Silk Road and also providing the planning and necessary schemes to clarify the tourism industry. The necessary interlocution must be done with the countries placed in initial path of the Silk Road seriously and these connections should be established closely with countries. Also 
effective actions must be done somehow the deprived cities and villages can be developed and at the same time their local worthiness must be kept. Also, protecting of the environment and attracting the public and local participation in projects and planning should be taken in priority.

Iran is known as an adverse tourist destination from different aspects including: Long distances to tourist centers of rich world, lack of necessary advertising, and the lack of comfort desired to spend time in travel and introducing our country as a land of severe people, religious, violent and despite the great tourist attractions did not succeed in attracting tourists who are interested to the traditions and culture, ancient heritage, virginal nature etc. [13], we must use the best advertising and show the serenity, intimacy, freedom, peace and security of the Islamic homeland to the world and finally the development of the deprived cities and villages should be done by using of the tourist attractions and expanding the tourism industry combined to the empathy and attunement with the countries along the Silk Road and we must use this valuable gift as a national property.

\section{References}

[1] Franck, B. and David, I. (2002) The Silk Road: A History. Soroush Publications, Tehran.

[2] Rezvani, M.R. (2008) Approach to Sustainable Development of Rural Tourism, Tehran University, Tehran.

[3] Molaei, H.N. (2012) The Local Administration, Ministry of Interior. The Center Mtalatbrnamh Urban and Rural Planning.

[4] Shieh, E. (2008) Degree in Urban Management, Urban Planning. Municipal Organizations and Village Administrations in the Country.

[5] Qaderi, Z. (2004) The Principle of Sustainable Rural Tourism Planning. Organization Municipalities and Dehdaris.

[6] East Newspaper (2015) Number, 2277. www.ghanoonbaz.com

[7] Reza, E. (2005) Iran's Role in the Silk Road Until the End of the Sassanian Era. Iran Recognition, Scientists Forum, Printing Mohammad Amin (p).

[8] Christensen, A.E. (2011) L' Iran sous les sassanides, The world of Book, Tehran.

[9] Dandamayev, M. (2010) Iranians in Achaemenid Babylonia. Cultural and Scientific Publications, Tehran.

[10] Sarvar, R. (2005) Ecotourism Attractions of Iran.

[11] Kargar, B. (2007) Development of Urbanization and Tourism Industry in Iran. Publications of Armed Forces Geographical Organization.

[12] Vaspur Engineering Company (2002)

[13] Kargar, B. (2009) Urban Security. Publications of Armed Forces Geographical Organization. 